\title{
Production and Marketing of Bricks in Srivilliputtur
}

\author{
P. Ramakrishnan
}

\begin{abstract}
It is estimated that India has more than 1,00,000 brick kilns producing about 250 billion bricks annually, employing about 15 million workers and consuming about 35 million tons of coal annually. The brick industry is growing as the demand for bricks is increasing in the towns and villages due to the fast economic growth, urbanization and prosperity. It is alarming to note that $300 \mathrm{~mm}$ depth of fertile top soil in India will be consumed for burnt clay brick production in about 60 years. Usually, brick kilns are situated in rural and or periphery of urban areas in the country. The secondary data is collected for the purpose of knowing history of brick industry in world and especially in India. It is found that the process of making a brick has not changed much over the centuries or across geographies. The brick sector in India is unorganized and is tremendous in size and spread. India is the second largest brick producer (China dominates with $54 \%$ share) in the world. The bricks industries have challenges like rapid increase in brick production, environmental concerns, use of large quantities of coal in brick kilns, use of good quality agriculture topsoil for brick production, shortage of workers, Increased competition etc. There is need to prepare action plan for sustainable development of Brick industry in India.
\end{abstract}

Keywords: Bricks, manufacturer, Production, Tractor, color

\section{INTRODUCTION}

Brick is one of the basic components of building industry. It gives more employment potential for rural poor people. The construction work is carried on large scale basis and the demand for brick is increasing day by day. Yet, bricks are manufactured in small scale and the brick units adopt primitive techniques modernization, improvement in technology or methods of production are not significant.

Brick is a small rectangular unit, usually of burned clay, used in the construction foundations, walls, piers, buttresses, and arches of Building and other structures and the duets, fuels, lining and chimneys of furnaces. By massing bricks in quantity, having massive or delicate preparations as required to loads, to provide screens or protection against the weather, or to resist the action of heat. Building brick can differ in size through individual countries set their own standard measurements. The method used to make bricks vary according to the raw material used, the intended use of the brick and other factors. However, the commercial production of bricks involves four basic steps such as preparing raw materials, forming bricks, drying bricks and fixing bricks.

Today building bricks remain important construction and decorative materials. A refractory brick is used for industrial production.

Revised Manuscript Received on December 09, 2019.

Mr.P.Ramakrishnan*, Assistant Professor, Department of Commerce Kalasalingam Academy of Research and Education Krishnankoil, Tamilnadu, India. Email: ramkhansai@gmail.com

\section{REVIEW OF LITERATURE}

The review of previous study on brick industry is essential to understand the concepts and the areas already studied so that new thrust areas hither to explore may be studied in detail. A few of the studies referred to by the researcher in relation to the present study is given as under: The researcher has studied the Encyclopedia, Britannica 1968. It gives an idea about the historical growth of the brick and various technologies in the brick making.

1. Heierli U, Maithel S (2008) - Brick By Brick: The Herculean Task of Cleaning Up the Asian Brick Industry by Swiss Agency for Development and Cooperation (SDC), Natural Resources and Environment Division, Berne. 2008. 2. Mr.R.Pothiraj has studied with the title on "Production and Marketing of Bricks in Rajapalayam Taluk in the year 2007. After 1989 no has studied about the problems of manufacturing and marketing of bricks at Srivilliputtur, Hence it is of special significance is study on "Production and Marketing of Bricks" in Srivilliputtur.

3. Mr. R.Thirupathi conducting a study on "Production and Marketing of Brick in Srivilliputtur" in the year 2005. He has mentioned in his study the main problems faced by the brick owners acute shortage of water.

4. Mr. N. Sundaram has conducted a project work on the production and marketing of bricks in Srivilliputtur in 1989. He pointed out in his study that inadequate finance problems is the main factor which affecting the production of bricks.

5. Mr.G.ChandraSekar, has done a research on "Production and Marketing of Bricks in Rajapalayam Taluk" in 1985. This study has highlighted the production and marketing problems of bricks in Rajapalayam

\section{STATEMENT OF THE PROBLEM}

This is an in depth study of various problems of production and marketing of bricks at Srivilliputtur. An analysis of this nature would certainly be benefitted from a brief discussion of the production of bricks in the past. Weather has a significant impact on production of bricks. In sunny days the production is maximum, and vice versa in rainy days. Since the work is mostly carried on in the open space, production is affected mainly by rainfalls.

Since brick manufacturers do not have own water resources, they get it from nearby wells by paying specified amount per tank or per hour. Own funds provided by the manufacturers as capital is less. 
Majority of them borrow funds from money lenders at very high rate of interest ranging from thirty six to fourty eight percent. The brick units at Srivilliputtur have faced so many problems in procuring sufficient raw materials, i.e. clay to the production process. They are due to inadequate finance, insufficient space for storing, impossibility of quarrying clay throughout the year as tanks are filled with rain water, reduction in the area for quarrying clay and prohibition of entry of vehicles into tanks due to babul plantations under social forestry, difficulty in getting vehicles in busy seasons, insufficiency of clay and sand permitted free of cost and continuance of quarrying clay without permit and higher cost of clay from leased private lands. Agricultural laborers engaged in brick manufacture go for more remunerative cultivation and harvest Operations during the busy season of agriculture. The workers are also absent themselves without intimating the employer, as brick burning, a hazardous work, and attributes danger to the workers. High cost and irregular supply of fuel affect the production, as it is to be brought from for away places like Madurai and other Towns. The work yard is inadequate for most of the brick manufacturers. Where the work yard is Leasehold at the end of the Lease period, the lesser either demands higher rentals for renewal or forces them to leave the land. The brick manufacturers have to yield to the demand of the lesser, as they could not get alternative places at economical rate. Marketing of bricks is yet another manifold problem which has direct bearing upon the prosperity of the brick manufacturers. Normally the price is settled by the interaction of the demand and supply. The brick manufacturer attributes the changes in price mainly to changes in supply of bricks. The supply is affected by rainfall which hampers production, non-availability of clay at normal rates, non-availability of required Labour during agricultural season, Shortage of fuel and inadequate water. Demand is affected by factors like sentiments to Start and Complete Construction in auspicious time, the variations in availability of cement, weather and economic conditions. Brick manufacturers face the risks of severe competition, non-collection of bills and Losses arising out of fluctuations in price. So the brick industry is study area face lot of problem for the production stage to marketing stage so the researcher has taken this topic to problem into the problems faced by brick industry is given suggestion for solving them.

\section{OBJECTIVES OF THE STUDY}

1. To analysis the production and marketing procedures in the study area.

2. To offer findings, suggestions and conclusion.

\section{SCOPE OF THE STUDY}

The growth of industries and housing in this area has increased the demand for bricks resulting in the establishment of many brick units. As no exclusive study has been made about the brick Industry at Srivilliputtur. The present Study covers mainly the problems of production, marketing and finance of Brick industry at Srivilliputtur.

\section{RESEARCH METHODOLOGY}

The present study is empirical in nature. An interview schedule is prepared for collecting the primary data from the brick makers and users. The secondary data were collected from the standard books, journals, and encyclopedia and research articles.

\section{PRIMARY DATA}

In order to have an in depth analysis to study into the problems of production and marketing of bricks, the first hand information is obtained from the owner of brick making units. Next a well structured interview schedule has been prepared. This interview schedule has been used for getting required data from the consumer of Bricks in the study area.

Interview Schedule is administered for this purpose. The fieldwork of this study is conducted during the period of the study. The interview was conducted both formally and informally through natural conversation in vernacular language i.e. in Tamil and is to be recorded by the adequate care is taken to obtain complete and correct information from the respondent.

\section{SAMPLING DESIGN}

In the study area there are 120 unorganized brick making units. Among the population units, the researcher has classified the units according to size. According to the sources of information, there are 20 small scale units (managed only by the family members), 90 medium scale units (hiring 20-25 Laborers) and 10 large scale units (employing 40-45 workers). The researcher has used stratified random sampling method for collecting data from the brick making units. The researcher has surveyed 50 percent of the total population Therefore the researcher has investigated 60 brick making units. Table1. Exhibits the number of sample units selected for the study.

TABLE NO: 1 SAMPLING DESIGN OF BRICK UNITS

\begin{tabular}{|c|c|c|c|c|}
\hline $\begin{array}{l}\text { S. } \\
\text { No }\end{array}$ & Category & $\begin{array}{c}\text { Popul } \\
\text { ation }\end{array}$ & $\begin{array}{c}\text { Percentage } \\
\text { of Units }\end{array}$ & $\begin{array}{c}\text { Sample } \\
\text { Units }\end{array}$ \\
\hline $\mathbf{1}$ & $\begin{array}{c}\text { Small Scale } \\
\text { Units }\end{array}$ & 20 & $50 \%$ & 10 \\
\hline $\mathbf{2}$ & $\begin{array}{c}\text { Medium } \\
\text { Scale Units }\end{array}$ & 90 & $50 \%$ & 45 \\
\hline $\mathbf{3}$ & $\begin{array}{c}\text { Large Scale } \\
\text { Units }\end{array}$ & 10 & $50 \%$ & 5 \\
\hline \multicolumn{2}{|c|}{ Total Sample } & $\mathbf{1 2 0}$ & & $\mathbf{6 0}$ \\
\hline
\end{tabular}

Source: Primary data

The researcher collects the primary data from different categories of respondents. It is very difficult to apply census method to collect the data. Hence convenient sampling technique has been adopted. The primary data are collected from 60 respondents from the study area.

TABLE No: 2 MARKETING CHANNEL OF BRICKS

\begin{tabular}{|c|c|c|c|}
\hline S.No. & Marketing & $\begin{array}{c}\text { No. of } \\
\text { Manufacturer }\end{array}$ & Percentage \\
\hline 1 & Direct customers & 10 & 17 \\
\hline 2 & Broker & 15 & 25 \\
\hline 3 & Retailer & 23 & 38 \\
\hline
\end{tabular}




\begin{tabular}{|c|c|c|c|}
\hline 4 & $\begin{array}{c}\text { Wholesaler \& } \\
\text { Retailer }\end{array}$ & 12 & 20 \\
\hline & Total & $\mathbf{6 0}$ & $\mathbf{1 0 0}$ \\
\hline
\end{tabular}

Source: Primary Data

From the above table it is known that 23 manufacturers selling the bricks through retailers, 15 of them selling the bricks through brokers, 12 manufacturers use wholesaler and retailer and 10 of them adopt direct selling method of bricks.

TABLE No: 3 MODE OF SALE OF BRICKS

\begin{tabular}{|c|c|c|c|}
\hline S.No. & $\begin{array}{c}\text { Mode of } \\
\text { Sales }\end{array}$ & $\begin{array}{c}\text { No .of } \\
\text { Manufactures }\end{array}$ & Percentage \\
\hline 1 & Cash Sales & 30 & 50 \\
\hline 2 & Credit Sales & 10 & 17 \\
\hline 3 & Both & 20 & 33 \\
\hline & Total & $\mathbf{6 0}$ & $\mathbf{1 0 0}$ \\
\hline
\end{tabular}

Source: Primary Data

It is clear from the above table that it is found that $50 \%$ of the manufacture to sell the bricks at cash sales, $33 \%$ of the manufacture to sell the bricks both cash and credit sales and remaining $17 \%$ of the manufacturers sell the bricks at credit sales.

TABLE NO: 4

SOURCES OF FINANCE TO CONSTRUCT BUILDING

\begin{tabular}{|c|c|c|c|}
\hline S.No. & Sources & $\begin{array}{c}\text { No. of } \\
\text { Respondents }\end{array}$ & Percentage \\
\hline 1 & Owned & 30 & 50 \\
\hline 2 & $\begin{array}{c}\text { Borrowed } \\
\text { Fund }\end{array}$ & 10 & 17 \\
\hline 3 & Both & 20 & 33 \\
\hline & Total & $\mathbf{6 0}$ & $\mathbf{1 0 0}$ \\
\hline
\end{tabular}

Source: Primary Data

From the above table it is clear that $50 \%$ of the respondents have used own funds to construct buildings and $33 \%$ of them used to purchase of bricks from owned and borrowed funds and the remaining $17 \%$ of them are construct the buildings of outside borrowings.

TABLE: 5

SOURCES OF PURCHASE OF BRICKS

\begin{tabular}{|c|c|c|c|}
\hline S.No. & Sources & $\begin{array}{c}\text { No. of } \\
\text { Respondents }\end{array}$ & Percentage \\
\hline 1 & $\begin{array}{c}\text { Direct from } \\
\text { Manufacturer }\end{array}$ & 20 & 33 \\
\hline 2 & Local traders & 13 & 22 \\
\hline 3 & Broker & 10 & 17 \\
\hline 4 & Mason & 17 & 28 \\
\hline & Total & $\mathbf{6 0}$ & $\mathbf{1 0 0}$ \\
\hline
\end{tabular}

Source: Primary Data

After analyzing the table fact that $33 \%$ of the people to purchase bricks direct from manufacturer and $28 \%$ of the customer to purchase the Bricks from through masons, $22 \%$ of the respondents to purchase through local traders and remaining $17 \%$ of customer are purchasing Bricks from through Brokers.

TABLE No: 6

\section{OPINION ABOUT THE PRICE OF BRICKS}

\begin{tabular}{|c|c|c|c|}
\hline S.No. & Opinion & $\begin{array}{c}\text { No. of } \\
\text { Respondents }\end{array}$ & Percentage \\
\hline 1 & High & 15 & 25 \\
\hline 2 & Low & 10 & 17 \\
\hline 3 & Reasonable & 35 & 58 \\
\hline & Total & $\mathbf{6 0}$ & $\mathbf{1 0 0}$ \\
\hline
\end{tabular}

Source: Primary Data

The researcher has analyzed the opinion about the price of bricks found that $58 \%$ of the respondents have opined that the reasonable price in Srivilliputtur bricks, $25 \%$ of the respondents opinion the bricks price is very high and remaining and remaining $17 \%$ of the respondents telling about the price of brick is very lower them the compared with other area brick.

TABLE No: 7

PEFERENCE OF BRICKS

\begin{tabular}{|c|l|c|c|}
\hline S.No. & Preference & $\begin{array}{c}\text { No. of } \\
\text { Respondents }\end{array}$ & Percentage \\
\hline 1 & Durability & 30 & 50 \\
\hline 2 & Color & 12 & 20 \\
\hline 3 & $\begin{array}{c}\text { Beautiful } \\
\text { look }\end{array}$ & 18 & 30 \\
\hline & Total & $\mathbf{6 0}$ & $\mathbf{1 0 0}$ \\
\hline
\end{tabular}

Source: Primary Data

It is revealed from the above table $50 \%$ of the customer to prefer the bricks durability, $30 \%$ of the respondents' preferences of bricks beautiful look and remaining $20 \%$ of the respondents are preference of the brick is good color.

TABLE No: 8

MODE OF TRANSPORT OF BRICKS

\begin{tabular}{|c|c|c|c|}
\hline S.No. & $\begin{array}{c}\text { Mode of } \\
\text { Transport }\end{array}$ & $\begin{array}{c}\text { No. of } \\
\text { Respondents }\end{array}$ & Percentage \\
\hline 1 & Lorry & 25 & 42 \\
\hline 2 & Tractor & 17 & 28 \\
\hline 3 & Mini door & 13 & 22 \\
\hline 4 & Bullock cart & 5 & 8 \\
\hline & Total & $\mathbf{6 0}$ & $\mathbf{1 0 0}$ \\
\hline
\end{tabular}

Source: Primary Data

It is clearly from the above table that $42 \%$ of the respondents are using the transport from Lorry, $28 \%$ of the respondents are using transport from tractor, $22 \%$ of the respondents are using

transport from Mini door and remaining $8 \%$ of the respondents are used transport of bricks from Bullock cart.

TABLE NO: 9

SUPPLY OF BRICKS

\begin{tabular}{|c|c|c|c|}
\hline S.No. & Opinion & $\begin{array}{c}\text { No. of } \\
\text { Respondents }\end{array}$ & Percentage \\
\hline 1 & $\begin{array}{c}\text { Fast in } \\
\text { delivery }\end{array}$ & & \\
\hline
\end{tabular}




\begin{tabular}{|c|c|c|c|}
\hline 2 & $\begin{array}{c}\text { Delay in } \\
\text { delivery }\end{array}$ & 19 & 32 \\
\hline 3 & $\begin{array}{c}\text { Damages in } \\
\text { delivery }\end{array}$ & 7 & 11 \\
\hline & Total & $\mathbf{6 0}$ & $\mathbf{1 0 0}$ \\
\hline
\end{tabular}

Source: Primary Data

An Examination of data in the above table that $57 \%$ of the respondents are opinion about the delivery of bricks in fast, $32 \%$ of the respondents are opinion from delivery of bricks in delay and $11 \%$ of the respondents are opinion from manufacturer is damages of supply.

\section{FINDINGS}

1. It is worthwhile to motion that 23 manufactures (38\%) follow the channel of retail selling.

2. It is worthwhile to mention that $50 \%$ of the manufactures sell the bricks for cash sales.

3. It is clear that the $50 \%$ of the respondent start the brick units in their own fund.

4. It is inferred that $33 \%$ of the respondents are prefer to purchase of bricks at directly frommanufacturers.

5. It is inferred that most $58 \%$ of the respondents telling about the price is the Srivilliputtur brick price is reasonable in nature.

6. It is observed that most of the respondents $50 \%$ of clear that the preference of the bricks from the customer is preference of durability.

7. It is felt to note from the fact that $42 \%$ of the respondents are getting bricks transport from lorry.

8. It is inferred that most $57 \%$ of the Brick makers to delivery of the bricks from manufacture to customer at quickly.

\section{SUGGESTIONS}

Brick manufactures by increase the production and marketing like domestic and international. There is a need to put the industry on the modern and scientific footing. Techniques and methods of production should be improved. The problem on productivity is essential to make use of available resources and constantly endeavoring to find out better. Cheaper, quicker and safe way of doing a job and manufacture a product should be identified. Brick manufactures may touch with from cooperative marketing society and sell at remunerative prices. This will help to avoid cutthroat competition. Further this will help to get loan from co-operative societies. The government may give support price for the bricks as most of the brick manufactures are village artisans leading hand to mouth life.

\section{CONCLUSION}

Government may sponsor programme to improve the techniques and method of production. New implements and modern tools may be provided at nominal rates. Research should be focused on how to make bricks at low cost without change the basic characteristics of labour - intensive industry.

Necessary modifications in clamps should be made to minimize the loss of energy. In addition that Commercial banks, Co-operative bank and rural banks can play a major role in the provision of finance at economical rate of interest and subsidy determines the profitability of brick manufactures. If sufficient funds are at their disposal, they can store sufficient clay, purchase desired type of fuel at the favorable terms, pay wages and advances in time, which will reduce labour turnover and increase their profit. To achieve this, the bank may liberally lend at differential rate of interest to the brick manufacturers. Security need not be insisted and purpose alone may be insisted. These measures will help to relieve the brick manufacturers from the clutches of moneylenders who take away a considerable portion of the profit. The bank may grant subsidy loan to the brick manufactures. It will reduce the burden of advancing to the workers and may reduce the chances of switching over of loyalty by the workers due to paucity of funds.

\section{REFERENCES}

[1] Palash Patraetal, (2015). A Study on Brick Kiln Industry in Pursura Block of Hooghly District, West Bengal. International Journal of Applied Research, Vol.1, Issue 9, pp 95-99.

[2] Wanjuleetal (2015). A Study of Rural Bricks Industries with Special Reference to Maharashtra Region. International Journal of Social Science \& Interdisciplinary Research, Vol. 4 (11), pp. 20-24.

[3] Kadam Avinash (2007). Environmental Impact Assessment of Brick Industry: With Special Focus on Soils. Enrich Environment Multidisciplinary International Research Journal Issue 1-3, Volume 1, pp 53-62.

[4] Rizwana Khan and Harish (2008). A Study of Impact of brick industries on Environment and human health In Ujjain city (INDIA). Journal of Environmental Research and Development Vol. 2 No. 3, pp 421-424.

Website:

https://en.wikipedia.org/wiki/Brick

https://en.wikipedia.org/wiki/Literature review

\section{AUTHORS PROFILE}

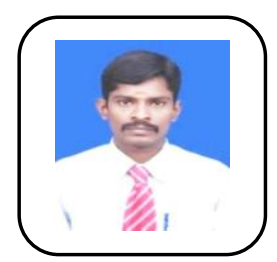

Mr.P.Ramakrishnan M.Com.,MBA.,M.Phil., SET., He is working as Assistant professor of commerce, Department of commerce, Kalasalingam Academy of Research and Education (Deemed to be University). Krishnan Koil. He has published in 3articles in National and international journal. He has 10 years of experience in two different colleges. 